\title{
RESPONSES OF EARTHWORM ABUNDANCE AND PRODUCTION OF SURFACE CASTS AND THEIR PHYSICO-CHEMICAL PROPERTIES TO SOIL MANAGEMENT IN RELATION TO THOSE OF AN UNDISTURBED AREA ON A SEMI-ARID TROPICAL ALFISOL
}

\author{
M. VIKRAM REDDY, ${ }^{*}$ V. RAVINDER REDDY, P. BALASHOURI, \\ V. P. K. KUMAR, A. L. COGLE,' D. F. YULE ${ }^{2}$ and M. BABU \\ 'Soil Biology Unit, International Crops Research Institute for the Semi-Arid Tropics (ICRISAT), \\ Patancheru 502324 A.P., India, ${ }^{2}$ Land Management Research Branch, QDPI, P.O. Box 1054 \\ Mareeba, QLD 4880, Australia and ' 3 and Management Research Branch, Queensland Department of \\ Primary Industries (QDPI), P.O. Box 6014 Rockhampton, QLD 4702, Australia
}

\author{
(Accepted 7 February 1996)
}

\begin{abstract}
Summary-Population densities of earthworms and their surface cast production were sampled across 15 soil management treatments such as annual tillages with organic amendments and perennial ley treatments during 1989-93 in a semi-acid tropical Alfisol. They showed significant reduction in their densities in annual treatments due to carbofuran and herbicide application during July 1989. In 1992, densities recovered from insecticide stress after 3 years, and showed significant temporal and spatial variation across the treatments, being higher during the post-rainy season. Soil management practices significantly affected the densities which were higher in zero-tillage farmyard manure treatment and in zero-tillage Stylosanthes and pigeonpea and Stylosanthes treatments among the annual and perennial treatments, respectively. Surface cast production of earthworms was higher in 1992 than in 1993, and was significantly affected by the annual treatments $(P<0.05)$. However, the physico-chemical properties such as $\mathrm{pH}$, electrical conductivity (EC), organic $C$, total $N$, available $P$, available $K, \mathrm{Na}, \mathrm{Ca}$ and $\mathrm{Mg}$ of casts were not affected by the annual and perennial treatments. The densities of earthworms, and their surface cast production were significantly greater in a natural revegetation area than those in the arable area under soil management, while most of the physico-chemical characteristics of casts were higher than those of the underlying soil in both arable and natural revegetation areas. (C) 1997 Elsevier Science Ltd
\end{abstract}

\section{INTRODUCTION}

Earthworms are one of the most important groups of beneficial soil invertebrates. Their abundance and activities in arable soils have been adversely affected by modern agriculture management practices such as mechanical tillage and indiscriminate use of pesticides. However, soil surface mulch management with crop residues and cover crops enhanced their densities (Lee, 1985). Unfortunately, very little information is available on the effects of various soil management practices on the structure and function of earthworm populations in tropical agroecosystems (Lal and De Vleeschauwer, 1982; Mulongoy and Bedoret, 1989; Anonymous, 1991). We report the effects of various tillage, organic amendments, and perennial ley treatments on the population structure of earthworms, and the production of surface casts

\footnotetext{
*Visiting Scientist (under the Rockefeller Foundation Environmental Research Fellowship in International Agriculture). Author for correspondence and present address: Environmental Biology Laboratory, Department of Zoology, Kakatiya University, Warangal 506 009 A.P., India.
}

and their physico-chemical properties in relation to those of an undisturbed natural revegetation area on a semi-arid tropical Alfisol.

\section{MATERIAL AND METHODS}

This experiment was conducted at the research farm of the International Crops Research Institute for the Semi-Arid Tropics (ICRISAT) Asia Centre, Patancheru (Long. $78^{\circ} 17^{\prime} 0^{\prime \prime} \mathrm{E}$, Lat. $17^{\circ} 28^{\prime} 58^{\prime \prime} \mathrm{N}$ and altitude c $547 \mathrm{msl}$ ) near Hyderabad, Andhra Pradesh (India) during July 1989 to November 1993, within a long-term soil management trial of balanced incomplete randomized block design, on a shallow-tomedium depth Alfisol field with hard setting soil (Patancheru series, Udic Rhodustalf). The experiment comprised 15 treatments: 3 tillage $(0 \mathrm{~cm}, 10 \mathrm{~cm}$ and $20 \mathrm{~cm}$ depth) $\times$ three organic amendments (bare, rice straw $5 \mathrm{tha}^{-1}$, farmyard manure $\left.15 \mathrm{tha}^{-1}\right)+6$ perennial ley treatments [Stylosanthes hamata $(S)$, Cenchrus ciliaris (C) and pigeonpea, Cajanus cajan (L) Millsp $(\mathrm{P})$ in sole and in combination $(\mathrm{P}+\mathrm{S}$, $\mathrm{P}+\mathrm{C}+\mathrm{S}$, and $\mathrm{C}+\mathrm{S})]$. Each treatment was 
replicated three times on $28 \times 5 \mathrm{~m}$ plot (Reddy et al., 1994).

Glyphosate, paraquat and atrazine at $41 \mathrm{ha}^{-1}$ were applied during pre-planting as well as during the crop season every year. Carbofuran granules at $4 \mathrm{~kg} \mathrm{ha}^{-1}$ were applied to the soil in the planting furrows to control the shootfly, Atherigona soccata R. in July 1989. These granules were again applied to the whorls of the Sorghum bicolor (L.) Moench seedlings during 1990. No insecticide was applied during 1991 to 1993. Fertilizers at $18 \mathrm{~kg} \mathrm{~N} \mathrm{ha}^{-1}$ and $46 \mathrm{~kg} \mathrm{P}^{\mathrm{P}} \mathrm{ha}^{-1}$ (diammonium phosphate) at planting, and $90 \mathrm{~kg} \mathrm{~N}$ $\mathrm{ha}^{-1}$ (urea) by side dressing, were applied every year.

Earthworm populations were sampled monthly by hand-sorting three randomly selected $25 \mathrm{~cm}^{2}$ areas upto $30 \mathrm{~cm}$ depth, on each of the 15 treatments during 1989 to 1993 , and at a nearby undisturbed natural revegetation area on the same soil type during 1992 to 1993. A $25 \mathrm{~cm}^{2}$ iron grid size was used for marking and digging the sampling area. The soil was carefully searched and the juvenile and adult earthworms were collected in separate polythene bags, and enumerated.

The production of surface casts of earthworms was measured during 1992-93 in each plot across the 15 treatments as well as at the natural revegetation area in five, $25 \mathrm{~cm}^{2}$, randomly selected areas. The casts were collected in separate polythene bags and oven-dried at $85^{\circ} \mathrm{C}$, and weighed and converted to production of casts $\mathrm{m}^{-2}$ area. About $250 \mathrm{~g}$ of casts from each treatment and those from the natural revegetation area and the underlying soils were air dried, sieved, and used for analyzing the physicochemical properties. The total $\mathbf{N}$ and available $P$ concentrations were analyzed by a Technicon $\Lambda$ uto Analyser-II (Industrial methods nos. 218-72A and 114-71A, respectively). The concentration of available $\mathrm{K}$, and $\mathrm{Na}, \mathrm{Mg}$ and $\mathrm{Ca}$ were estimated by the triacid digestion method (Jackson, 1967) and atomic absorption spectrophotometry (Varian, AA201).

The population densities of adult and juvenile earthworms, production of surface casts and their physicochemical properties were computed for statistical significance using analysis of variance (GENSTAT).

\section{RESULTS AND DISCUSSION}

Earthworms sampled across the 15 treatments during 1989-93 belonged to two species: Octochaetona phillotti (Michaelsen) and Lampito mauritii Kinberg, the former being dominant, while those of the undisturbed natural revegetation area belonged to there species: $O$. phillotit, $L$ mauritti and Octonochaeta rosea (Stephenson). The number of species did not differ across the 15 treatments indicating little influence of the soil management practices on the earthworm species diversity (Gerard and Hay, 1979).
The population densities of juvenile and adult earthworms showed significant temporal and spatial variations, with the densities of juveniles higher than those of adults across all treatments (Fig. 1). Densities were significantly higher during the post rainy season than the rainy season $(P<0.01)$. Earthworms were not recorded during the dry winter and summer, probably because of the very dry soil conditions; the worms probably moved to the deeper layers of soil and entered into a quiescent stage or died during the process (Lee, 1985). The population densities were high during July 1989 before the application of carbofuran, and gradually declined from August (Fig. 1).

The densities in the annual tillage and organic amendment treatments during the 1989-91 crop seasons were lower than those in 1992. There was a distinct yearly variation in the population densities of both adults and juveniles across the soil management treatments (Fig. 2). The reduction in densities in annual treatments during 1990 and 1991 was probably due to the synergistic ecotoxic effects of carbofuran and herbicides (Edwards and Bohlen, 1992). The populations gradually build up and recovered from the insecticide stress during 1992 after three years, followed by a reduction in density during 1993. The reduction was probably due to the extensive sampling of earthworms (for other experiments).

The population densities of earthworms were

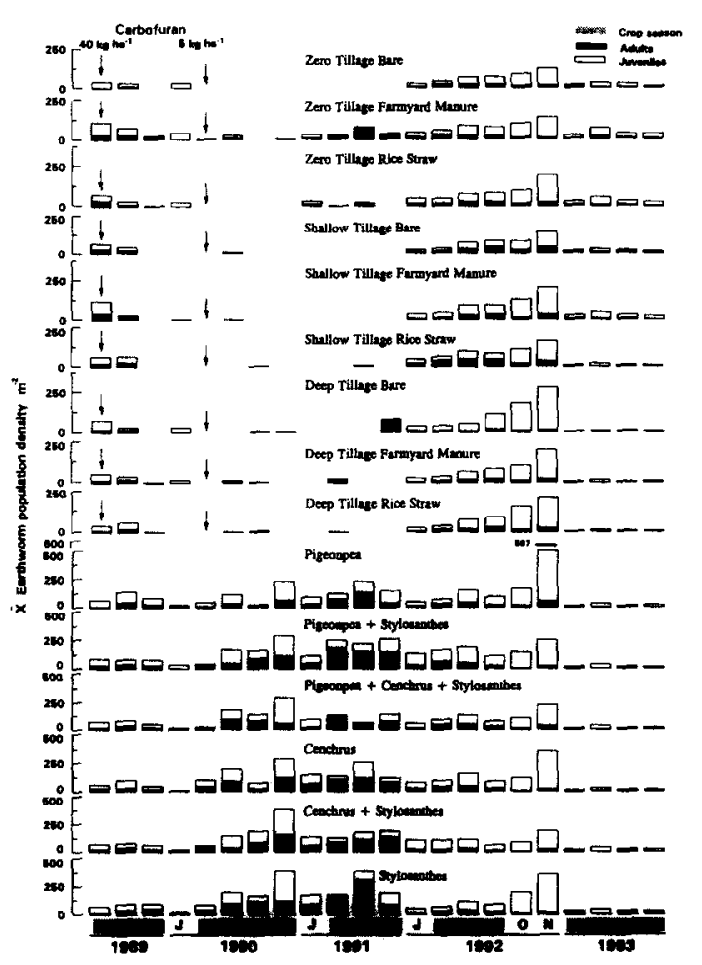

Fig. 1. Monthly variation in mean population densities of earthworms across the 15 soil management treatments during wet seasons (1989-93), as affected by Carbofuran in annual tillage and organic amendment treatments. 


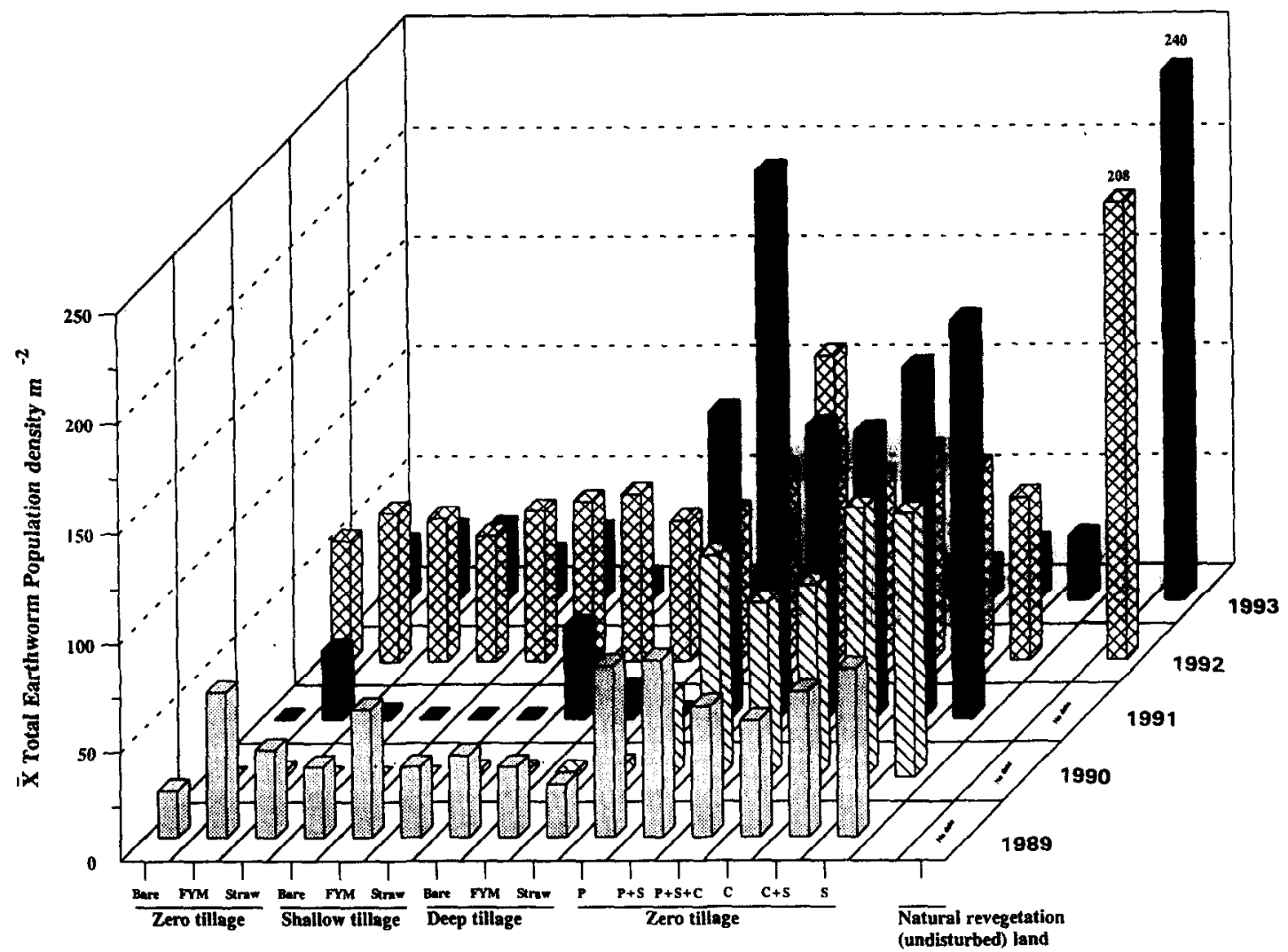

Fig. 2. Population densities $(\bar{X})$ of earthworms across 15 soil management treatments during 1989-93, in relation to those in the natural revegetation area during 1992-93.

significantly higher in the perennial treatments than the annual treatments with tillage and organic amendments, particularly during 1989 to 1991 $(P<0.05)$. It was most probably because of the availability of greater amount of decomposed plant residue as food, and consistently favourable and unperturbed microclimate for the activities of earthworms. Among the annual treatments, the zero-tillage farmyard manure treatment recorded higher densities of earthworms than those in other annual treatments. This may be attributable to cowdung as an important source of food, and to less soil disturbance (Gerard and Hay, 1979; Lee, 1985; Kladivko and Timmenga, 1990; Hendrix et al., 1992). The total earthworm population densities were even higher in some of shallow and deep tillage treatments during 1989, 1991 and 1992, but the reasons for such increase are not known. Among the perennial treatments, densities were higher in treatments with more vegetation especially the leguminous cover, such as $S$. hamata contributing $\mathrm{N}$ to soil than in treatments such as pigeonpea, with less soil cover (Barley, 1959).

The average population densities of earthworms in natural revegetation area during 1992 to 1993 were 3 to 6 times higher than those in the annual treatments and 2.5 to 3.5 times higher than those of the perennial treatments $(P<0.05)$ (Fig. 2). The decline in densities in arable land, particularly in the annual treatments, clearly indicates the deleterious effects of soil management on earthworms (Anonymous, 1991).

The rate of cast production was higher during the 1992 crop season than that in 1993 (Fig. 3), and was higher in the perennial treatments than that in annual treatments. Cast production was significantly affected by the tillage and organic amendments treatments $(P<0.05)$. However, it did not show any significant variation across the perennial treatments $(P<0.5)$. The cast production in the natural revegetation area was 10 to 12 times that of the arable area under soil management (Fig. 3). Soil management treatments did not show any noticeable influence on any of the physico-chemical properties of casts, such as $\mathrm{pH}$, electrical conductivity (EC), organic $\mathrm{C}$, total $\mathrm{N}$, available $\mathrm{P}$, available $\mathrm{K}, \mathrm{Na}, \mathrm{Ca}, \mathrm{Mg}$. The $\mathrm{pH}$ of casts and of the underlying soil in the arable area was acidic while that in the natural revegetation area was alkaline. The $\mathrm{pH}, \mathrm{EC}$, organic $\mathrm{C}$, total $\mathrm{N}$ and $\mathrm{Ca}$ of the casts of the natural revegetation area were higher than those of the arable area, indicating the difference due to different earthworm species. All the values of these physico-chemical properties of casts, except $\mathrm{Na}$ and $\mathrm{Ca}$ in the arable area, were higher than those of the underlying soil of both arable and natural revegetation areas. Organic $C$ and available $P$ and $K$ 


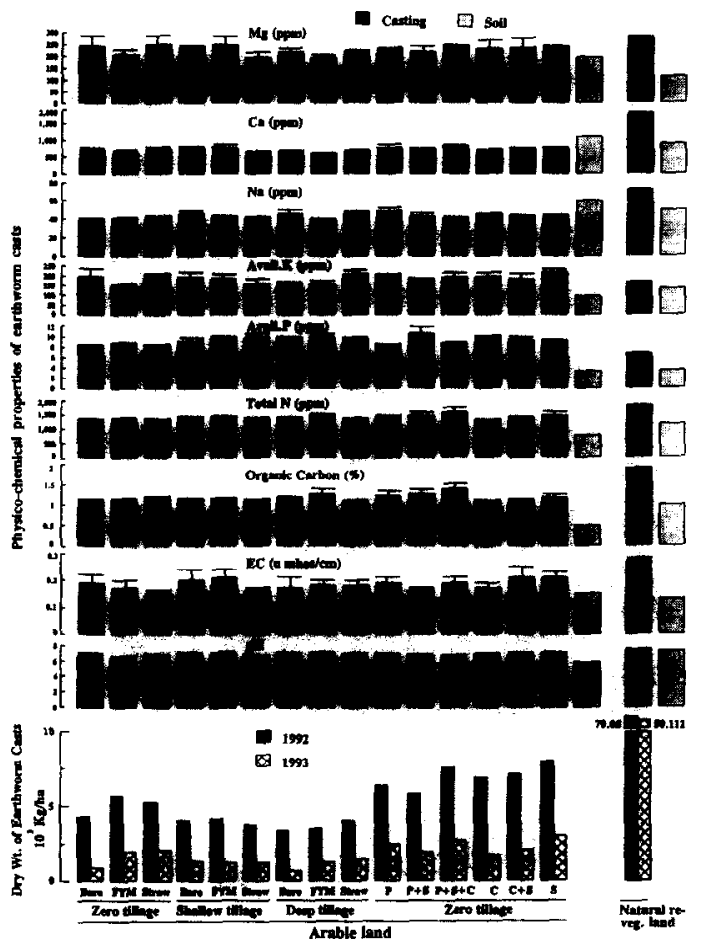

Fig. 3. Variation in production of surface casts during $1992-93$ and in their physico-chemical properties across the 15 soil management treatments in relation to natural revegetation area and underlying soils.

were many times higher in casts than those of the underlying soil in the arable area. These observations confirm the findings of Lee (1985) and Mulongoy and Bedoret (1989).

Acknowledgements-The present research work would not have been possible without the support from the Rockefeller Foundation (New York, U.S.A.) through an Environmental Research Fellowship in International Agriculture to MVR
(RF grant no. 89094 \#6), and ICRISAT (Patancheru, India). Dr J. M. Julka (ZSI, Solan) identified the earthworms.

\section{REFERENCES}

Anonymous (1991) Earthworms in ICRISAT Report 1990. Patancheru, A.P., 502 324, India: ICRISAT.ISSN 1017-9933, pp. 102-104.

Barley K. P. (1959) The influence of earthworms on soil fertility. 1. Earthworm populations found in agriculture land near Adelaide. Australian Journal of Agricultural Research 10, 171-178.

Edwards C. A. and Bohlen P. J. (1992) The effects of toxic chemicals on earthworms. Reviews of Environmental Contamination and Toxicology 125, 24-99.

Gerard B. M. and Hay R. K. M. (1979) The effect on earthworms of ploughing, tined cultivation, direct drilling and nitrogen in a barley monoculture system. Journal of Agriculture Science (Cambridge) 93, 147-155.

Hendrix P. F., Mueller B. R., Bruce R. R., Langdale G. W. and Parmelee R. W. (1992) Abundance and distribution of earthworms in relation to landscape factors on Georgia piedmont, U.S.A. Soil Biology \& Biochemistry 24, 1357-1361.

Jackson M. L. (1967) Soil Chemical Analysis. Prentice Hall of India, New Delhi.

Kladivko E. J. and Timmenga H. J. (1990) Earthworms and agriculture management. In Rhizosphere Dynamics (J. E. Box Jr. and L. C. Hammond, Eds), pp. 192-216. American Association for the Advancement of Science Selected Symposium 113

Lal R. and De Vleeschauwer D. (1982) Influence of tillage methods and fertilizer application on chemical properties of worm castings in a tropical soil. Soil and Tillage Research 2, 37-52.

Lee K. E. (1985) Earthworms: their Ecology and Relationships with Soils and Land Use. Academic Press, Sydney. Mulongoy K. and Bedoret A. (1989) Properties of worm casts and surface soils under various plant covers in humid tropics. Soil Biology \& Biochemistry 21, 197-203.

Reddy M. V., Reddy V. R., Yule D. F., Cogle A. L. and George P. J. (1994) Decomposition of straw in relation to tillage, moisture, and arthopod abundance in a semi-arid tropical Alfisol. Biology and Fertility of Soils $17,45-50$ 